\title{
Shifting the Absolute Competence of State Administrative Justice in the Indonesian Legal System
}

\author{
Despan Heryansyah \\ Constitutional Law, Law Faculty, Islamic University of Indonesia, Yogyakarta, Indonesia
}

Email address:

Despan.her@gmail.com

\section{To cite this article:}

Despan Heryansyah. Shifting the Absolute Competence of State Administrative Justice in the Indonesian Legal System. International and Public Affairs. Vol. 4, No. 2, 2020, pp. 28-34. doi: 10.11648/j.ipa.20200402.12

Received: October 3, 2019; Accepted: November 1, 2019; Published: August 25, 2020

\begin{abstract}
The element of "administrative justice in government" in the concept of rechstaat, whereas in the concept of rule of law there is no element, is a very fundamental different from the two concepts of this rule of law. The existence of administrative justice in the rechstaat concept is motivated by the government's authority to normalize all regulations in the form of statutory regulations, thus providing administrative justice as a forum for the public to seek justice. In Indonesia the authority to examine government policies related to citizens' rights is placed in a separate judicial institution, namely the State Administrative Court. PTUN's existence cannot be separated from the commitment of the Indonesian people to establish a rule of law and protect the interests of its citizens. In connection with that, Law Number 5 of 1986 concerning State Administrative Court was established as a material form of law as well as formally regarding government administration in Indonesia. 28 years after its formation, this law was considered to be no longer relevant in responding to the challenges of the times, especially in protecting the interests of the people from the arbitrariness of the authorities. Therefore, in 2014 the government and the House of Representatives passed Law Number 30 of 2014 concerning Government Administration in which regulating a great number of new competencies for PTUN outside the competencies that had existed before. Some topics in this research are related to what the forms of expansion of the absolute competence of PTUN in the government administration law are, how the problems of implementation are, and what the implications for the Indonesian legal system are. The methode of this reasearch is juridical normative, where data will be enriched by conducting interviews with PTUN judges in several regions in Indonesia. The results showed that there were several forms of expansion of the absolute competence of PTUN, such as the authority to test factual actions, to test the abuse of authority, to test administrative efforts, to break positive fictitious decisions, and to test discretion. The problem found in the field was the lack of socialization carried out by the central government, including the Supreme Court, so that it still caused confusion for the judges. Meanwhile the implications faced after the enactment of this law on the Indonesian legal system are that many articles which, besides having ambiguous meanings, are also in conflict with the doctrines and theories of administrative law that have been adhered to by experts.
\end{abstract}

Keywords: Competence, Administrative, Legal System, PTUN

\section{Introduction}

A human thought or conception is an age child born and raised in a state of histories with its various influences. The human thought or conception of the state of the law is also born and flourishes in a historical state. [1] The concept of the law state grows rapidly, in which initially all the power of the state was delegated to a king who shaped the law, administered the government, and conducted the functions of justice directly. The highest decisions were in the hands of the king, so whatever the king decided should be carried out with various consequences. Even in the early medieval times, the king's power was compared to the power of God, and the king's decision was God's will. Realizing that this concept was becoming more and more kingly to the citizens, the power of the king began to diminish. [2] Then, a formal model of state law developed.

The formal lowstate lasted only a few moments and was considered to be no longer relevant because it only made the country a night watchman, having no authority to interfere in 
all matters of state. Then came the concept of a modern legal state, [3] which placed the government as the party responsible for the welfare of its people. The main characteristic of this country was the emergence of the government's obligation to realize the general welfare of its citizens. [4]

This thinking about the rule of law state reached its peak in the 19th century with the emergence of the concept of the rechtstaat of Freidrich Julius Stahl, inspired by the ideas of Immanuel Khant. According to Stahl the elements of the rule of law are as follows: [5]

1. Protection of human rights;

2. Separation or distribution of powers to guarantee those rights;

3. Government based on legislation; and

4. Administrative justice in disputes.

In the Anglo-Saxon region, the concept of rule of law of the A. V. Dicey appeared with the following elements: [6]

1. (Supremacy of the law).

2. (Equality before the law).

3. Guaranteed human rights by law.

The existence element of "administrative justice in government" in the concept of rechstaat, but it does not in the concept of rule of law that element does not exist, is a very fundamental difference from the two concepts of this rule of law. The administrative justice in the rechstaat concept is motivated by the government's authority in normalizing all regulations in the form of statutory regulations/legislation, so administrative justice as a forum for the public to seek justice is provided.

Besides, the most basic characteristics of legal actions taken by the government are unilateral decisions and decrees. [7] It is said to be one-sided because whether or not a government legal action is carried out depends on the unilateral will of the government. Decisions and decrees as a government legal instrument in carrying out unilateral legal actions may be a cause of violations of the law for citizens, especially in a modern law state that gives broad authority to the government to interfere in citizens' lives. Therefore we need legal protection for citizens against government legal actions. Thus, an administrative court was formed in order that people get legal certainty in seeking justice. [8]

The Position of the State Administrative Court in the 1945 Constitution of the Republic of Indonesia after the amendment has been explicitly regulated, Especially in Article 24 Paragraph (2) of the 1945 Constitution. The explicit arrangement of the State Administrative Court position in the constitution is influenced by the idea of the need to improve the quality of supervision of the government since the potential for abuse of authority from government officials is increasingly clearly detrimental to the general public. [9] Provisions regarding material laws and formal law from the State Administrative Court are then regulated in Law No. 5 of 1986 concerning State Administrative Courts.

The absolute competence of the Administrative Court is contained in article 47 of the Law on Administrative Court which stipulates that the court has the duty and authority to examine, decide upon, and resolve state administrative disputes. Administrative dispute, according to Article 1 number 4, is a dispute arising in the field of state administration between a person or a legal entity with a state administration agency, both at the central and regional levels, as a result of the issuance of the Administrative Decree State, including employment disputes based on applicable laws and regulations. [10]

From the provisions in Law No. 5 of 1986 it seems that the competence of State Administrative Court is very narrow, only related to the State Administration Decree considered detrimental to the community. Decisions as known must be concrete, individual and final. Apart from them, the State Administrative Court has no authority to adjudicate them. The above conditions have lasted for nearly 20 years, and in line with the increasing tasks that must be carried out by the government influenced by the understanding of the welfare state, in addition to the government's authority to discretion, namely freedom to take policy if there is no law governing it or a vague law that belongs to the government. Therefore, the competence of the State Administrative Court contained in Law No. 5 of 1986 is no longer relevant, because it is too narrow to only hear decisions that are concrete, individual and final.

In order to extend the protection of the law to the public from being a victim of governmental entitlements, in 2014 Law No. 30 of 2014 on Government Administration was passed. This law extends the competence of the State Administrative Court which not only judges the National Business Decree but also empowers it to adjudicate other matters in relation to the state administration. The State Administrative Court is empowered to judge whether or not the decision of a state-owned enterprise is abusive.

The extension of the absolute competence of the Administrative Court certainly causes legal consequences, both formal and material, and in practice there are also new problems arising. Therefore, it is necessary for the writer to study it in the form of a paper in the subject of the State Administration Court. From the description above, the formulation of the problem in this paper is as follows: What is the shift form in the absolute competence of the State Administrative Court in Law No. 30 of 2014? What are the implications of the shift in absolute competence in the State Administrative Court?

\section{Analysis}

\subsection{Absolute Competence of State Administrative Court Law According to Law No. 5 of 1986}

Generally, in procedural law there is an authority (competency) of a judicial body to examine and try a case. The competency is divided into relative and absolute competencies. Relative competency is the authority of a court to adjudicate a case in accordance with its jurisdiction, while absolute competence is the authority of a court in accordance with the object or material or subject matter of the dispute. [11] What the writer will discuss in this paper is the absolute competency of administrative justice. 
Absolute competency is related to the authority of the Administrative Court to examine and adjudicate a dispute according to the object or material or principal of the dispute. Even though state administrative bodies / officials can be sued at Administrative Court, not all actions can be tried by it.

The actions of state administrative bodies / officials that can be sued in Administrative Court are regulated in Article 1 paragraph (3) and Article 3 of Law No. 5 of 1986, while the remaining actions become the competency of the General Courts or Military Administrative Courts or even for the problem of making regulations (regeling) made by the government and of a general nature. The one who has the authority to adjudicate it is the Supreme Court through the Right to Judge Material. [12]

Article 47 of Law No. 5 of 1986 states: the court has the duty and authority to examine, decide, and settle state administrative disputes. What is a state administration dispute? Article 1 number 4 of Law No. 5 of 1986 also formulates disputes arising in the field of state administration, both at the central and regional levels, as a result of the issuance of state administrative decisions, including staffing disputes based on applicable laws and regulations. [13]

Thus, the State Administrative Decision is the basis for the birth of a state administration dispute. What is the State Administrative Court? Article 1 number 3 formulates it as a written stipulation issued by a state administration agency or official which contains an act of state administrative law based on applicable legislation that is concrete, individual and final, leading to legal consequences for a person or entity civil law.

With the above elements, the understanding of the State Administrative Court has not yet been completed. Additionally, there are some points listed in article 3, ie in the case of that a state administration body or official does not issue a decision being petitioned to him, while that is his obligation. The period of time determined is four months from the receipt of the application if the laws and regulations do not specify it.

Even though a state administration decision has fulfilled the elements and or characteristics as referred to in Article 1 number (3), there is a decision that cannot be included as the State Administrative Court's competence, so it cannot be the object of a state administration dispute. Some of these restrictions are found in Article 2, Article 48, Article 49, Article 142 and the general explanation of Law No. 5 of 1986. Sjachran Basah classifies the restrictions into two groups, namely direct and non-direct restrictions. [14]

First, direct restrictions are those that make it impossible for the State Administrative Court to examine and decide on the dispute. This direct limitation is contained in Article 2, Article 49, General Explanation. According to Article 2, those that are not included in the State Administration Decree according to this Law are:

1. The decision on state administration in the form of a general arrangement;

2. State administrative decisions that constitute civil law;

3. The State Administrative Decision that still needs approval;
4. The State Administrative Decision issued based on the Criminal Code and Criminal Procedure Code and other laws and regulations that are criminal in nature;

5. The State Administrative Decision issued based on the results of a judicial body examination of the provisions of the applicable laws and regulations;

6. The State Administrative Decision regarding ABRI (now TNI);

7. The decision of the Election Committee both at the center and in the regions regarding the results of the general election.

Based on Article 49, the State Administrative Court has no authority to examine, decide on, and settle certain state administrative disputes in the event that the dispute of the state administration decision is issued:

1. In times of war, danger, natural disaster or extraordinary circumstances in accordance with applicable laws;

2. In an urgent need for the public interest in accordance with applicable laws.

According to general explanation number (1) administrative disputes within the Armed Forces and in military matters, which are according to the provisions of Law No. 26 of 1953 and Law No. 19 of 1958, are examined, decided upon and resolved by the Military Administrative Court.

Second, the non-direct limitation is a limitation on absolute competence that still opens the possibility for appeal level State Administrative Court to examine and resolve state administrative disputes provided that all administrative efforts available for this have been taken. [15] Based on this non-direct restriction, the dispute must first be resolved through administrative efforts. If the administrative effort has been picked up but the plaintiff has not yet been satisfied, the lawsuit can be directly submitted to the High State Administrative Court.

Returning to the issue of state administrative disputes, from the above provisions, it can be seen that state administrative disputes consists of the following elements:

a) Disputes arising in the field of national business;

b) The dispute between a person or a civil law bodies and the State Agency or Business Office;

c) The dispute referred to as a result of the issuance of a State Business Decision.

Elucidation of Article 1 (4) states that the term "dispute" which is intended from the provisions contained in Article 1 (4) has a special meaning in accordance with the functions of the State Administrative Court. Article 1 Number 1 determines that State Administration is the one that carries out functions to carry out government affairs, both at the central and Regional level. [16]

"Government affairs" in Article 1 Number 1, by the explanation of Article 1 Number 1, are mentioned as an executive activity. When talking about executive activities, we inevitably have to talk about the Trias Politica theory from Montesquieu, which is that state power is divided into three parts,

a) Legislative, namely the power that makes laws and regulations; 
b) Executive, namely the power that implements the rules;

c) Judiciary, namely the power that oversees / adjudicates violations of the regulation.

Therefore, from the point of view of the theory of trias politica, it can be seen that "executive activities" are activities that are implementing the law. The question is whether the State Administration only carries out functions to carry out activities which are the implementation of laws and regulations.

In practice, state administration not only carries out functions to carry out activities that are in the implementation of laws and regulations, but also performs functions to resolve important and urgent government affairs that have not been regulated in legislation, for example in the face of disasters (floods, earthquake, and so on). Basically the government both implements the law and on the basis of "freies ermessen" c does other acts even though it has not been explicitly regulated by law. [17]

However, there is a dilemma regarding this freies ermessen. Because all the policies of the state administration officials are stated on the grounds of freies ermessen or discretion, there are no provisions governing the testing. The provisions of Law No. 5/1986 also do not regulate, so the State Administrative Court feels not to have the competence to examine, decide upon and resolve them. Meanwhile, the potential for abuse of authority in the presence of discretion is even greater.

Then it has been mentioned by Article 1 Number 4 that what is also under the authority of the State Administrative Court is "staffing disputes based on applicable laws and regulations". The question is what an employment dispute means based on applicable laws.

Article 5 of Law No. 8 of 1974 determines that dispute resolution in the field of staffing is carried out through the judiciary, for the purpose as part of the state administration referred to in Law No. 14 of 1970 concerning the Principal Provisions on Judicial Power. From these provisions it can be seen that before Law No. 8/1970 amended by Law No. $43 / 1999$ the legislators had the intention to establish an employment court as a special court within the PTUN.

However, with the change of Law No. 8 of 1974 to Law No. 43 of 1999, it is apparent that the requirements of the law were changed, as Article 35 of Law No. 8 of 1974 was amended into three Clauses, which Section (1) defines "a personal dispute as resolved through State Business Judiciary ". Thus, it can be seen that the "dispute of personnel under the applicable law" in the formulation of the provisions contained in Article 1 paragraph (4) is a labor dispute under Law No. 8 of 1974 Jo. Law No. 43 of 1999.

In accordance with the definition of State Business Dispute as contained in Article 1 paragraph (4), the Personnel Dispute is a dispute arising in the State Business Administration between a person who is a State Officer with the Agency or a State Business Office, both at the center and in the region as a result of the issuance of the State Business Decree in the field of personnel.

\subsection{Absolute Competency Shift of the State Administrative Court}

In accordance with Article 1 paragraph (2) of the 1945 Constitution of the Republic of Indonesia, sovereignty is in the hands of the people and is carried out according to the Basic Law. Furthermore, according to the provisions of Article 1 paragraph (3) of the 1945 Constitution of the Republic of Indonesia, the state of Indonesia is a state of law. This means that the administration of the government of the Republic of Indonesia must be based on the principle of people's sovereignty and the rule of law. Based on these principles, all forms of government decisions and / or administrative actions must be based on popular sovereignty and law which is a reflection of Pancasila as the state ideology. Thus, it is not based on the power inherent in the state administration position itself.

The wider authority by the government as a result of the application of the conception of the welfare state will further open up the potential for abuse of authority. Certainly, those who will become victims are the people; therefore, it needs strict regulations relating to government administration so that the people have legal certainty and avoid victims of abuse of authority. In this regard, in 2014 the first Administrative Law was born in Indonesia, namely Law No. 30 of 2014 concerning Government Administration.

Even though it has received a lot of criticism from various groups because there are many contradictions and confusions, the Law is obligatory to be obeyed by all citizen because the Law has been ratified in the State Gazette. This law regulates many administrative provisions in Indonesia, including shifting the competence of the State Administrative Court. The State Administrative Court in Law No. 5 of 1986 only has the authority to adjudicate decisions (beshicking) issued by the government (executive) and staffing disputes only. However, in Law No. 30 of 2013, the State Administrative Court has even broader absolute competence. The form of shifts in Law No. 30 of 2014 are:

\subsubsection{Administrative Scope}

In Law No. 5/1986, the scope of administration is only in the executive field, namely implementing the law and in practice coupled with the authority of government officials to issue discretion. However, in Law No. 30 of 2014 there is an expansion of the scope of administration, namely maintaining administration in the executive field and the administration in other fields of power. Article 4 states:

1) The scope of Government Administration arrangements in this Act includes all activities:

a) Government Offices and / or Officers that carry out Government Functions within the scope of executive institutions;

b) Government Offices and / or Officers that carry out Government Functions within the scope of the judiciary;

c) Government Offices and / or Officers that carry out Government Functions within the scope of the legislative body; and 
d) Other Government Offices and / or Officials that carry out the Government Functions mentioned in the 1945 Constitution of the Republic of Indonesia and / or laws.

2) Government Administration Arrangements as referred to in paragraph (1) cover the rights and obligations of government officials, government authority, discretion, administration of government administration, government administrative procedures, government decisions, administrative efforts, fostering and developing government administration, and administrative sanctions.

Thus, the consequences of the above provisions are that the case submitted to the Administrative Court is not only in the field of government administration by the executive as it has happened so far, but also in other areas of governmental power, namely the judiciary and legislative branches. This provision actually raises problems, what if one day an administrative problem arises with the judiciary itself? How will the objectivity of the Administrative Court decide and resolve it?

\section{Judging Abuse of Authority}

The extent of government authority to intervene in the lives of citizens increasingly opens opportunities for abuse of authority by state administration officials. The welfare state on the one hand can indeed protect the public from the powerlessness in the face of global competition, but on the other hand it also opens up opportunities for the abuse of state administration officials. Therefore, protection is needed for citizens from the possibility of abuse of authority from this state administration official, so that this Law also regulates the authority of the State Administrative Court to examine whether a Decree and / or Actions of State Administration Officials contains abuse of authority or not. In Law No. 5/1986 this has not been regulated, so abuse of authority is still in the State Court. Article 17 states:

1) Government agencies and / or officials are prohibited from abusing authority.

2) Prohibition of abuse of authority as referred to in paragraph (1) includes:

a) the statute goes beyond the authority;

b) Prohibition to confound authority; and / or

c) the prohibition to act arbitrarily.

In Article 19, it is again stated:

1) Decisions and / or Actions prescribed and / or made in excess of the Authorities as referred to in Article 17 paragraph (2) letter a and Article 18 paragraph (1) and Decisions and / or Arbitrary Acts and / or actions as referred to in Article 17 paragraph (2) letter c and Article 18 paragraph (3) are invalid when already tested and there is a Court of Judgment in force of law.

2) Decisions and / or Actions prescribed and / or made in combination with the Authorities as referred to in Article 17 paragraph (2) letter b and Article 18 paragraph (2) may be revoked if already tested and a Court Decree is in force.

The two Articles have explicitly stated that the Judiciary has the right to declare a decision and / or act of a state administration official whether or not there is an abuse of authority. Then it is increasingly emphasized again in Article 21, which are:

1) The court is entitled to receive, examine, and determine whether or not there is an element of abuse of authority committed by the Government Office.

2) The Agency and / or Government Officer may apply to the Court to determine whether or not there is an element of abuse of Authorization in the Decision and / or Action.

3) The court shall decide the application as referred to in paragraph (2) within 21 (twenty-one) business days of the application.

4) The decision of the Court as referred to in paragraph (3) may be appealed to the State Business Court of Appeal.

5) The State Administrative Supreme Court shall decide the appeal as referred to in paragraph (4) within 21 (twenty-one) business days of the appeal being filed.

6) The decision of the State Administrative Supreme Court High Court as referred to in paragraph (5) is final and binding.

From the provisions of Article 21 above, the authority to declare a decision and / or act of a state administration official whether or not there is an abuse of authority belongs to the State Administrative Court. Thus, the competence of its decision has broadened again, even as previously discussed that the Agency and / or Government Officials in this Law is not only in the executive field, but also in the legislative and judicial fields.

\subsubsection{Trying the Discretion of the State Administration Officer}

Indonesia as a country carrying out the principle of popular sovereignty [18] based on the law [19] as the author has stated above legitimates that Indonesia is a state of law. The consequence of this statement is that all actions and policies issued by the government must comply with statutory regulations. All policies issued not based on statutory regulations can be said as arbitrary acts or unauthorized acts and can be canceled by law. This is the basic conception of the implementation of governance in Indonesia, but because of the limitations of this principle or because of the weaknesses and deficiencies contained in the legislation, the government is given freedom of freies ermessen or discretion, which is the independence of the government to enable to act on initiative itself in solving social problems. [20] According to Ridwan HR, the practice of this freies ermessen opens up opportunities for conflicts of interest between the government and citizens. [21]

Dealing with the above, theoretically the responsibility for discretion is needed. Given the use of discretion opens up opportunities for the abuse of authority by the State Administrative officials, this Law also has accommodated the examination of discretion issued by state administration officials. If the discretion contains an element of abuse of authority, it can be canceled by a court decision. Article 30 of the Act states: 
1) The use of discretion is categorized as exceeding authority if:

a) Acting beyond the time limit for the validity of the Authority granted by the provisions of the legislation;

b) Acting beyond the borders of the validity of the Authority granted by the provisions of the legislation; and / or

c) Not complying with the provisions of Article 26, Article 27, and Article 28.

2) The legal consequences of using Discretion as referred to in paragraph (1) become invalid.

Article 31

1) The use of Discretion is categorized as confusing authority when:

a) It is not in accordance with the purpose of the Authorized Authority;

b) It does not comply with the provisions of Article 26, Article 27, and Article 28; and / or

c) It opposes to $A U P B$.

2) The legal consequences of the use of Discretion as referred to in paragraph (1) may be canceled.

Article 32

1) The use of Discretion is categorized as an arbitrary action if issued by an unauthorized official.

2) The legal consequences of using Discretion as referred to in paragraph (1) become invalid.

The expansion of the State Administrative Court's competence in testing discretion is a form of shifting to the old doctrine stating that each power is prohibited from interfering with the authority of other powers. Executives are prohibited from interfering in judicial affairs in conducting justice and likewise judiciary is prohibited from meddling in government affairs where the field of government is executive authority. However, in today's modern state, where the role of the state is expected in all aspects of people's lives, in order to avoid the abuse of authority, the judiciary is allowed to interfere in executive matters in the context of monitoring and protecting the rights of citizens.

\subsection{Problems of Shifting Absolute Competence in Law No. 30 of 2014}

The shift in absolute competence of the State Administrative Court raises several problems, both in theory and in the field. In the discussion of this paper several issues relating to the relaxation and implementation of the Act will be addressed, related to the extension of its competency. Some of the problems are as follows:

\subsubsection{The Existence of Administrative Efforts Is Still Admitted}

One problem that is still caused by Law No. 5 of 1986 is the existence of administrative efforts considered to reduce the authority of the State Administrtative Court. Meanwhile, of almost all administrative efforts undertaken, none shows the success of this effort. This is caused by several problems contained in this administrative effort, namely: Lack of procedural law, lack of information, assessment of policy aspects, determination of deadlines and lack of facilities. Then after administrative efforts are made, the first-level State Administrative Court no longer has the right to try them but has to appeal directly. The Law No. 30 of 2014 does not regulate the elimination of administrative efforts so that the existence of administrative efforts is still justified.

\subsubsection{Disruption of Terminology Meaning}

In this Law No. 30 of 2014, the terms and / or actions are widely used. This provision has received a lot of criticism from the administration's lawyers. The phrase "decision and / or action" has a confusing meaning, because theoretically the action is the genus of all decisions made by state officials, whether in the form of regelling, beshicking, consent, and so on. Therefore, does this action include all those decisions? Then why does it use the phrase "decision and / or action", while the decision is part of the action itself. In practice, this would complicate the State Administrative Court in judging, as well as open up the possibility of independent interpretations that are based solely on the needs of certain groups.

\subsubsection{Human Resource}

Since 1986, the State Administrative Court's authority has been limited to beshicking and staffing disputes, but with Law No. 30 of 1984 this authority is expanded in such a way. Surely, this dynamic will have an impact on the human resources owned by it, both judges, clerks, or other components. Judges and court clerics are certainly educated to solve beshicking and staffing disputes, because that is what the State Administrative Court is formed for. Therefore, for the trial process to proceed properly and the decision in favor of justice, adjustments must be made first. In the first judicial process of this Law, which involved PT TUN Medan and the famous lawyer O. C. Kaligis, it turned out to be a problem. Judges and lawyers are involved in bribery cases and are currently being investigated by the KPK. This indicates the vulnerability of this law to abuse if it is not accompanied by improvements in human resources.

\subsubsection{Legal Standing Problems}

Article 21 Paragraph (2) states that the Agency and / or Government Officers may apply to the Court to determine whether or not there is an element of abuse of Authorization in the Decision and / or Action. It is further clarified by the existence of the procedural Law No. 30 of 2014, that the Supreme Court Rules (PERMA), in this Article 2 of PERMA, state that the applicant in the assessment of whether or not there is abuse of authority is the body and / or governmental authority. This means that the applicant is entitled to be the applicant for the Governmental office and / or Officer.

This provision is very strange, because it removes the legal standing of ordinary people to do the testing, whereas the community is the object of the decision of the state administration official. In the sense, the community is the victim of the abuse of authority. Then the community should also be given the authority to be the petitioner. 


\subsubsection{Authority to Adjudicate the Implementation of Judicial Functions}

In Law No. 30 of 2014, the State Administrative Court is given the authority to adjudicate Government Agencies and / or Officers that carry out Government Functions within the scope of the judiciary. The question is whether it is possible if the Administrative Court can objectively try cases in its own institution. Even in principle, the authority to judge oneself is not justified.

These are several of the problems arising from the application of Law No. 30 of 2014 concerning Government Administration. We realize that there is no perfect human work in this world; however; a critical analysis of a product of legislation is still needed for the establishment of a better legal system to go forward.

\section{Conclusion}

In Law No. 5/1986, the State Administrative Court is only given the authority to adjudicate cases of beshicking and personnel disputes. However, due to the increasingly widespread government intervention in the lives of citizens as a consequence of the conception of the welfare state, the protection of citizens from abuse of authority by the State Administration Officials is also tightened. The step used is to provide legal remedies for the community if he feels that he has been harmed by the decision of the State Administrative official who has misused authority, including in terms of discretion. Therefore, in Law No. 30 of 2014 the competence of State Administrative Court has become wider, so that it can decide whether there is abuse of authority in a State Administration Decree as well as testing for discretion released by the State Administrative Officer.

The shift in competence of the State Administrative Court causes several problems, both in terms of what is contained in the Law and in the effort to implement them. These problems include the recognition of the existence of administrative efforts, the chaos in the terminology of "decisions and / or actions" because theoretically the two terms have very basic differences, Human Resources (HR) owned by it (judges, clerks and others) have not been educated to try new absolute competencies that they have, those who have legal standing in this Law are only the State Administrative Agencies or Officers, whereas ordinary people are not, and finally the authority to adjudicate Government Agencies and / or Officials that carry out Government Functions within the scope of the objectivity of the judiciary can be questionable since it is similar to the State Administrative Court that adjudicates itself.

\section{References}

[1] Ridwan HR, Hukum Administrasi Negara, Cetakan keenam, (Jakarta: Rajawali Pers, 2011), hlm. 1.

[2] Yaitu dengan lahirnya magna charta, sebuah perjanjian antara Raja Jhon Inggris dengan para Bangsawan yang pada pokoknya berisi pemberian hak-hak kepada para bangsawan dan pengurangan kekuasaan yang dimiliki oleh Raja. Konsepsi tentang negara terus mengalami perkembangan hingga pada perjanjian Montevideo kemudian pembagian kekuasaan oleh Jhon Locke dilanjutkan Montesqiueu dalam bukunya "L'Esprit des Lois". (Perkuliahan Pertama HAN dengan Dr. Ridwan, SH., M. Hum),

[3] Konsepsi negara demikian memiliki berbagai macam istilah, antara lain: Walfare State, socal service state, bestuurzorg, social rechstaat. Lihat S. F. Marbun, Peradilan Administrasi Negara dan Upaya Administratif fi Indonesia, Cetakan Kelima, (Yogyakarta: UII Press, 2011), hlm. 189. juga dikenal dengan istilah negara hukum material, dan Moh Hatta menyebutnya dengan negara pelayan.

[4] Ridwan HR, Hukum Administrasi Negara, Cetakan keenam, (Jakarta: Rajawali Pers, 2011), hlm. 5.

[5] Philip M. Hadjon, Perlindungan Hukum bagi Rakyat di Indonesia, (Surabaya: Bina Ilmu, 1987), hlm. 16-82.

[6] Miriam Budiardjo, Dasar-dasar Ilmu Politik, cetakan pertama, (Jakarta: Gramedia, 1982), hlm. 58.

[7] Philipus M. Hadjon, Op. Cit. hlm. 124.

[8] Ridwan, Hukum Administrasi Negara, (Yogyakarta: UII Press, 2002), hlm. 226.

[9] W. Riawan Tjandra, Peradilan Tata Usaha Negara; Mendorong Terwujudnya Pemerintahan yang Bersih dan Berwibawa, (Yogyakarta: Universitas Atma Jaya, 2009). Hlm. 1.

[10] R Wiyono, Hukum Acara Peradilan Tata Usaha Negara, Cetakan Peratama, (Jakarta: Sinar Grafika, 2007) hlm. 5.

[11] SF Marbun, Peradilan Administrasi Negara dan Upaya Administratif Di Indonesia, Cetakan Ketiga, (Yogyakarta: UII Press, 2011, hlm. 239.

[12] Moh Mahfud MD, Lingkup Kompetensi Peradilan Tata Usaha Negara dan Kapasitas Tuntutan atas Satu Tuntutan Administrasi, dikutip dari SF Marbun, Ibid. hlm. 41.

[13] Phulipus M Hadjon, dkk., Pengantar Hukum Administrasi Indonesia (Introduction to the Indonesian Administrative Law), Cetakan Keenam, (Yogyakarta: Gadjah Mada University Press, 1999), hlm. 318.

[14] Sjachran Basah, Beberapa Hal tentang Hukum Acara Administrasi, FH UNPAD Bandung, dikuti dari SF. Marbun, Op. Cit. hlm. 242-245.

[15] Pasal 48 UU No 5 Tahun 1986.

[16] R. Wiyono, Op. Cit. hlm. 5-6.

[17] Philipus M Hadjon dkk., Pengantar Hukum Administrasi... Op. Cit. hlm 138.

[18] Pasal 1 ayat 2 UUD Negara Republik Indonesia Tahun 1945 (Pasca Amandemen).

[19] Pasal 1 ayat 3 UUD Negara Republik Indonesia Tahun 1945 (Pasca Amandemen).

[20] Utrecht, Pengantar Hukum administrasi Negara Indonesia, (Surabaya: Pustaka Tinta Mas, 1988), hlm. 30.

[21] Ridwan HR, Op. Cit. hlm. 230. 